\title{
Design, Delivery, Maintenance, and Outcomes of Peer-to-Peer Online Support Groups for People With Chronic Musculoskeletal Disorders: Systematic Review
}

Liam R Maclachlan ${ }^{1^{*}}, \mathrm{PhD} ;$ Kathryn Mills ${ }^{2^{*}}, \mathrm{PhD}$; Belinda J Lawford ${ }^{3}, \mathrm{PhD}$; Thorlene Egerton ${ }^{3}, \mathrm{PhD}$; Jenny Setchell ${ }^{1}$, $\mathrm{PhD}$; Leanne M Hall ${ }^{1}, \mathrm{PhD}$; Melanie L Plinsinga ${ }^{1}, \mathrm{MSc}$; Manuela Besomi ${ }^{1}$, MSc; Pek Ling Teo ${ }^{3}$, MHSc; Jillian P Eyles $^{4,5}$, PhD; Rebecca Mellor ${ }^{1}$, PhD; Luciano Melo ${ }^{6}$, BSc; Sarah Robbins ${ }^{4,5}$, PhD; Paul W Hodges ${ }^{1}$, DSC, MedDr, $\mathrm{PhD}$; David J Hunter ${ }^{4,5}$, MD, PhD; Bill Vicenzino ${ }^{1}$, PhD; Kim L Bennell ${ }^{3}, \mathrm{PhD}$

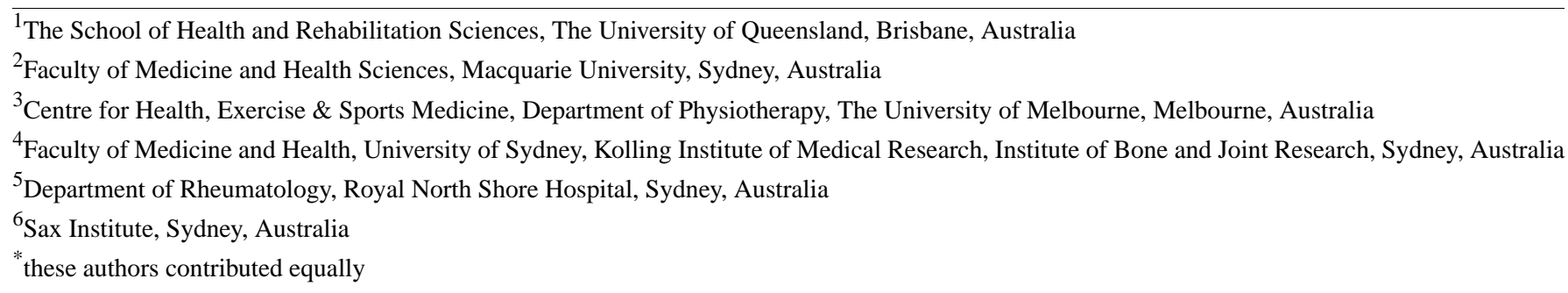

Corresponding Author:

Kathryn Mills, PhD

Faculty of Medicine and Health Sciences

Macquarie University

Physiotherapy Ground Floor, 75 Talavera Road

Macquarie Park

Sydney, 2019

Australia

Phone: 61298506624

Email: Kathryn.mills@mq.edu.au

\section{Abstract}

Background: Online support groups (OSGs) are one way for people with chronic diseases, their family or friends, and health professionals to communicate, gain information, and provide social support. As the number of peer-to-peer OSGs for chronic musculoskeletal conditions grows, it is important to gain insight into the different designs of groups available, who is accessing them, if and how they may be effective, and what strategies are being used to implement or increase consumer engagement.

Objective: The objectives of this systematic review of people with musculoskeletal conditions were to (1) describe the design features (functions, usage options, moderation, and expert input) of peer-to-peer OSGs, (2) describe the characteristics of the individuals using peer-to-peer OSGs, (3) synthesize the evidence on outcomes of participation, and (4) identify strategies used in the delivery and maintenance of OSGs.

Methods: A search comprising terms related to the population (people with musculoskeletal disorders) and the intervention (peer-to-peer OSGs) was conducted in 6 databases. Results were filtered from 1990 (internet inception) to February 2019. Studies identified in the search were screened according to predefined eligibility criteria using a 2-step process. Quantitative studies were appraised by 2 reviewers using the Risk Of Bias In Non-Randomized Studies of Interventions tool. Qualitative studies were appraised by 2 different reviewers using the Critical Appraisal Skills Programme checklist. Extracted data were synthesized narratively.

Results: We examined 21 studies with low to moderate risk of bias. Of these studies, 13 studies included OSGs hosted on public platforms, 11 studies examined OSGs that were conducted in English, and 6 studies used moderators or peer leaders to facilitate engagement. Studies either reported the number of OSG members ( $\mathrm{n}=1985$ across all studies) or the number of posts (range: 223-200,000). The majority of OSG members were females who were not full-time employees and with varied levels of education. There were no randomized controlled trials measuring the efficacy of OSGs. Qualitative and quantitative studies identified empowerment, social support, self-management behavior, and health literacy as primary constructs to measure OSG efficacy. 
Neutral or marginal improvement was reported in these constructs. Sharing experiences and a greater level of engagement appeared to have an important influence on OSGs efficacy. The extent to which members posted on the website influenced engagement.

Conclusions: Across a diverse range of designs, languages, included features, and delivery platforms, peer-to-peer OSGs for chronic musculoskeletal conditions attract predominantly female participants of all ages and education levels. The level of participation of a member appears to be related to their perceived benefit, health literacy, and empowerment. Future studies are needed to identify which design and maintenance strategies have superior efficacy and whether there are concomitant improvements in health outcomes for people with chronic musculoskeletal conditions resulting from participation in OSGs.

Trial Registration: PROSPERO International Prospective Register of Systematic Reviews CRD42018090326; https://www.crd.york.ac.uk/prospero/display_record.php?ID=CRD42018090326

(J Med Internet Res 2020;22(4):e15822) doi: 10.2196/15822

\section{KEYWORDS}

social support; musculoskeletal diseases; online social networking; empowerment

\section{Introduction}

\section{Background}

Chronic musculoskeletal disorders are highly prevalent [1], the leading cause of nonfatal disease burden [2], and include conditions (such as low back pain) that are the leading cause of disability internationally [3]. Musculoskeletal disorders disrupt daily living and account for a large proportion of lost productivity in the workplace [4]. Given that there is no cure for many chronic musculoskeletal disorders, long-term self-management is a core recommendation of clinical guidelines $[5,6]$. Central to effective long-term management is patient education and advice relating to medication, therapeutic exercise, general physical activity, weight loss (if appropriate), and potentially beneficial physical and psychological treatments [6-8].

Another key factor in the management of musculoskeletal disorders is social support, as it may positively influence health behaviors susceptible to social influence [9]. Social support may also buffer the negative impact of low health literacy [10]. Both are essential in negotiating health care systems [11] and may impact health outcomes. For example, in individuals with hip and knee osteoarthritis, increased social support has been associated with higher levels of health-related quality of life [12]. Conversely, in those with rheumatoid arthritis, low levels of social support at the time of diagnosis have been predictive of poorer functional disability and pain outcomes 5 years later [13].

Online support groups (OSGs) are one way in which people with chronic musculoskeletal disorders can access social support and information. OSGs range from self-initiated groups on social media (eg, Facebook) to custom-developed websites run by clinicians or organizations. Their common goal is to provide opportunities for people to share experiences, advice, and support for their chronic disorders [14]. Given that a United Nations report (December 7, 2018) reported that more than 50\% of the world's population now has access to the internet and that Web-based health service usage is increasing, OSGs may provide an accessible, convenient, and efficient means of augmenting social support and self-management. To date, the research pertaining to the characteristics of OSG platforms, group members, and implementation strategies is varied, and there is little focus on individuals with chronic musculoskeletal disorders. This makes it difficult to draw conclusions regarding if and how they are clinically effective or have a role in musculoskeletal health care.

\section{Objectives}

This study aimed to systematically review the literature evaluating the use of peer-to-peer OSGs for people with chronic musculoskeletal disorders. The 4 objectives of this review were to (1) describe the design features of peer-to-peer OSGs, (2) describe the characteristics of individuals involved in peer-to-peer OSGs, (3) synthesize the evidence on the effectiveness of OSGs, and (4) identify implementation strategies used in the delivery of OSGs.

\section{Methods}

\section{Review Registration}

The Preferred Reporting Items for Systematic Reviews and Meta-Analyses statement was used to ensure complete reporting, and the review protocol was registered in the International Prospective Register of Systematic Reviews (CRD42018090326).

\section{Search Strategy}

The search strategy was developed in consultation with a librarian from The University of Queensland and involved 2 components: the population (people with chronic musculoskeletal disorders) and the intervention (peer-to-peer online support). The full PubMed search strategy is shown in Multimedia Appendix 1. The following electronic databases were searched: PubMed, CINAHL, EMBASE, PsycINFO, Scopus, and PubMed Central. A time-based filter was implemented, capturing all potential studies from 1990 (year inception of the internet) to February 26, 2019. The search included both keywords and subject heading terms. Supplementary searches of reference lists of included studies were undertaken.

\section{Study Selection}

Studies involving OSGs for adults ( $>18$ years) with chronic (>3-month duration) musculoskeletal disorders (ie, disorder that primarily affects the musculoskeletal system) were considered eligible. Eligible interventions included any peer-to-peer (ie, 
participants interacting) OSG (>3 participants on an online platform) with or without moderation or expert input or supervision. Observational studies, cohort studies, case-control studies, randomized controlled trials, qualitative studies, and mixed method studies were eligible for inclusion.

Studies not available in English and studies of pediatric populations and animals were excluded. Telehealth interventions, where health care consultations are delivered remotely via phone or internet, were excluded. Studies that used online peer-to-peer support as part of a combined or complex intervention were only included if the OSG component of the intervention was examined as an independent component, and data were available for extraction. In studies that investigated a range of morbidities, extracted data were limited to those from individuals with musculoskeletal disorders. Studies in which data pertaining to musculoskeletal disorders were not presented separately and could not be extracted were included if musculoskeletal disorders accounted for the majority of cases and authors could provide these data when contacted. When multiple studies were identified from the same groups of authors, they were contacted to determine whether samples used were independent or the same across studies. When no response was received, samples that were similar in terms of musculoskeletal disorder and year of recruitment were assumed to be the same and included only once in the analysis.

Using the eligibility criteria described above, a 2-step process was used for screening and selection. Titles and abstracts of all identified studies were screened by any 2 of the 4 reviewers (LM, MP, MB, and RM) using Covidence (Covidence, Melbourne, Australia). Additional reviewers (KM, JE, and TE) were asked to resolve screening disagreements. Full-text articles of all eligible studies were retrieved and screened by any 2 of the reviewers mentioned above, with conflicts resolved by discussion.

\section{Data Extraction}

The authors worked in 4 groups (1 for each research question) to extract data using custom-developed spreadsheets. For the first research question relating to the design features of OSGs, the following data were extracted: (1) presence and type of moderation or expert input; (2) functions and design features of host platforms; (3) content, frequency, and volume of member posts and information uploaded; and (4) involvement from participants. The second research question regarding member characteristics involved the extraction of demographics, roles and relationships, and health disorders. For the third research question relating to the effectiveness of OSGs, the following data were extracted: (1) the constructs by which effectiveness was measured, (2) outcome measures utilized to quantify effectiveness constructs, (3) processes and themes explaining any benefits, and (4) results of effectiveness studies or satisfaction ratings. For the fourth research question relating to implementation strategies, the following data were extracted: (1) group development and initiation strategies, (2) where the group was hosted, and (3) barriers and enablers to engagement in support groups.

\section{Assessment of Study Quality}

Qualitative studies were evaluated with the Critical Appraisal Skills Programme (CASP) checklist [15]. The CASP involves 10 questions divided into 3 sections: (1) validity of the results (questions 1 to 6), (2) reporting of results (questions 7 to 9), and (3) utility of the results (question 10). Moreover, 2 of the 3 reviewers (JS, TE, and KM) independently assessed the included qualitative studies. Conflicts were resolved through discussion until consensus was reached.

Quantitative studies were appraised with the Risk Of Bias In Non-Randomized Studies of Interventions tool (ROBINS-I) [16]. The ROBINS-I assesses 7 domains of bias divided across 3 timepoints: preintervention (confounding and selection bias), at intervention (classification of the intervention), and postintervention (deviation from the intervention, missing data, measurement error, and reporting bias). A total of 2 authors (LH and KM) performed the assessment, with any conflicts resolved until consensus was reached. The overall risk of bias was determined by the triangulation of results across all domains.

\section{Data Synthesis}

A narrative synthesis of findings was conducted because of the heterogeneity in the type of OSG, evaluation measures used, and population and designs of the included studies.

\section{Results}

\section{Study Selection}

The process of study selection is shown in Figure 1. The search yielded 19,947 articles. Following the removal of duplicates, 14,991 titles and abstracts were screened. Of these, 50 full-text articles were considered, from which 20 studies were eligible for the review. 
Figure 1. Study eligibility flow.

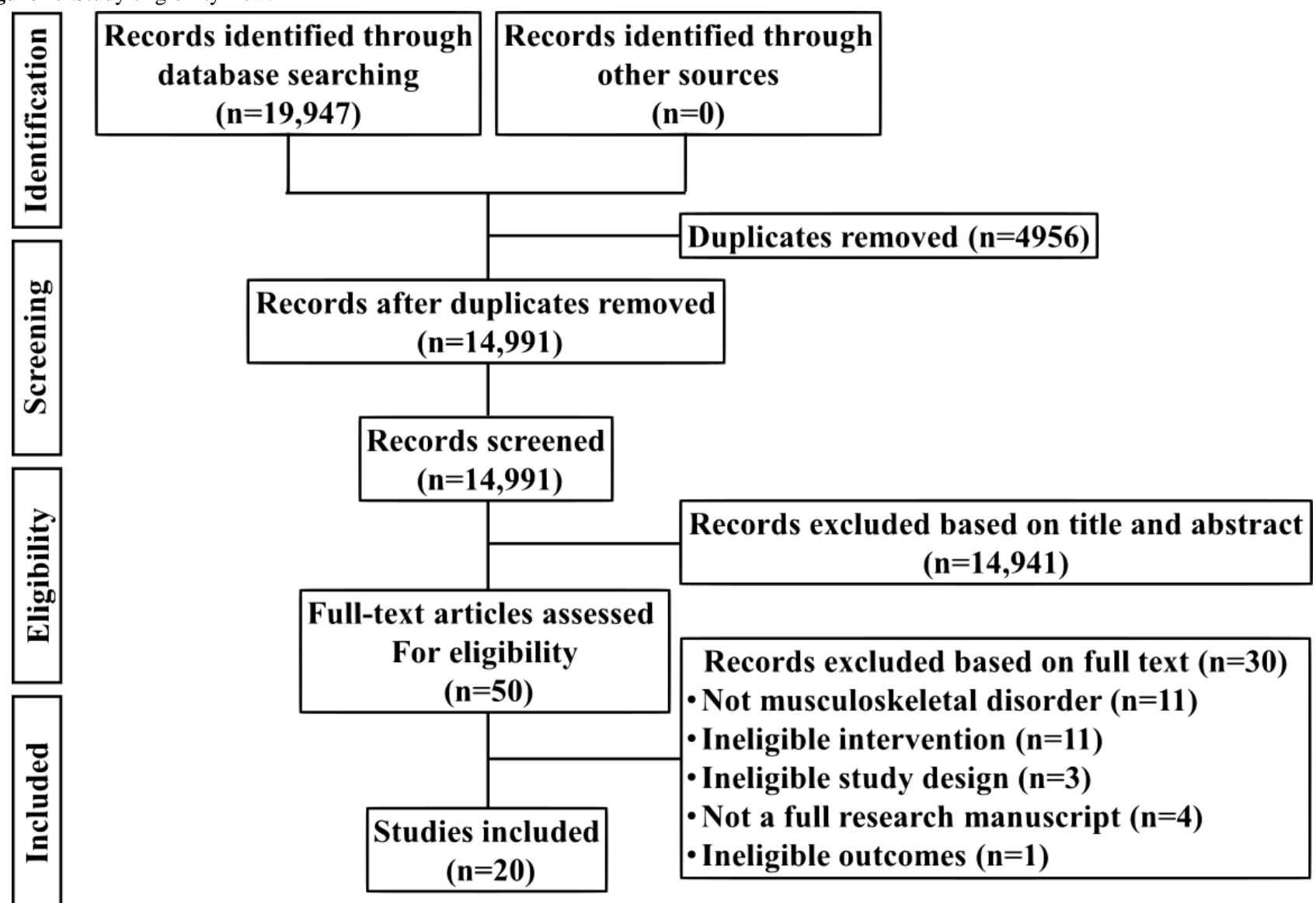

\section{Study Characteristics}

Description of the design, sample size, and aims of the included studies is shown in Table 1. Overall, 10 studies were qualitative, 7 were quantitative, and 3 employed both qualitative and quantitative components. In terms of study design, 3 studies were prospective and the rest were cross-sectional. None of the studies were randomized controlled trials. We found 3 studies that used data from the same OSGs in the Netherlands but had different foci: forum leaders $(n=32)$ [17], all participants $(n=528)$ [18], or compared posters (people who write comments on OSG pages) with lurkers (people who read material without contributing posts; $n=109$ ) [19]. Moreover, 2 studies used the discourse of the same 20 members from 4 arthritis-related OSGs in the United States [20,21], and a third study by the same authors examined 1960 posts from the same 4 OSGs [22].

\section{Study Quality}

\section{Quality Assessment of Qualitative studies}

Of the 20 included studies, 13 included a qualitative component. On average, studies met 7.4 (out of 10) CASP items. Most did not articulate how interviewer perspectives may have influenced their findings. One study met 3 of the 10 criteria, implying poor methodological quality and inability to confirm the validity of findings [23]. Multimedia Appendix 2 provides full details of the quality assessment of qualitative studies. A study [24] that described the design and development of an online community without undertaking a formal qualitative evaluation was excluded from the quality assessment. 
Table 1. Design, sample size, and aims of included studies.

\begin{tabular}{|c|c|c|c|c|}
\hline References & Country $^{\mathrm{a}}$ & Study design & $\begin{array}{l}\text { Sample size/sam- } \\
\text { ple volume }\end{array}$ & Study aim \\
\hline $\begin{array}{l}\text { Ammerlaan et al } \\
{[25]}\end{array}$ & The Netherlands & $\begin{array}{l}\text { Prospective feasibility } \\
\text { (participant survey) }\end{array}$ & 12 members & $\begin{array}{l}\text { To test the feasibility of the Web-based and face-to-face } \\
\text { self-management program }\end{array}$ \\
\hline Bright et al [26] & United Kingdom & $\begin{array}{l}\text { Retrospective online par- } \\
\text { ticipant survey }\end{array}$ & 152 respondents & $\begin{array}{l}\text { To identify the characteristics and motivations of Web- } \\
\text { based health information seekers accessing the Web-based } \\
\text { health community }\end{array}$ \\
\hline Camerini et al [27] & Switzerland & $\begin{array}{l}\text { Retrospective online par- } \\
\text { ticipant survey }\end{array}$ & 209 respondents & $\begin{array}{l}\text { To evaluate the effectiveness of an internet-based patient } \\
\text { education intervention }\end{array}$ \\
\hline $\begin{array}{l}\text { Hadert and Rodham } \\
\text { [28] }\end{array}$ & United Kingdom & $\begin{array}{l}\text { Retrospective, qualita- } \\
\text { tive, interpretive, phe- } \\
\text { nomenological analysis }\end{array}$ & $\begin{array}{l}374 \text { members, } \\
1068 \text { posts }\end{array}$ & $\begin{array}{l}\text { To investigate how and why an arthritis Web-based mes- } \\
\text { sage board was used }\end{array}$ \\
\hline Shigaki et al [29] & United States & Retrospective, qualitative & 30 participants & $\begin{array}{l}\text { To evaluate social interactions among individuals with } \\
\text { rheumatoid arthritis participating in an empirically based, } \\
\text { cognitive-behavioral, self-management, peer support pro- } \\
\text { gram delivered in a Web-based format }\end{array}$ \\
\hline Smarr et al [24] & United States & Feasibility & $\begin{array}{l}114 \text { members, } \\
448 \text { posts }\end{array}$ & $\begin{array}{l}\text { To describe the Web-based transformation of an empirically } \\
\text { validated, clinic-based, self-management program for } \\
\text { rheumatoid arthritis }\end{array}$ \\
\hline Smedley et al [30] & United Kingdom & $\begin{array}{l}\text { Retrospective qualitative } \\
\text { content analysis }\end{array}$ & $\begin{array}{l}23 \text { members, } 223 \\
\text { posts }\end{array}$ & $\begin{array}{l}\text { To explore the experiences of members in a newly launched } \\
\text { complex regional pain syndrome discussion forum to ex- } \\
\text { amine how support processes become established }\end{array}$ \\
\hline Smedley et al [31] & United Kingdom & $\begin{array}{l}\text { Retrospective, qualitative } \\
\text { thematic analysis }\end{array}$ & $\begin{array}{l}59 \text { moderators, } \\
790 \text { posts }\end{array}$ & $\begin{array}{l}\text { To identify and describe the activities performed by Web- } \\
\text { based support community moderators }\end{array}$ \\
\hline $\begin{array}{l}\text { van Uden-Kraan et } \\
\text { al [17] }\end{array}$ & The Netherlands & $\begin{array}{l}\text { Semistructured inter- } \\
\text { views }\end{array}$ & 32 participants & $\begin{array}{l}\text { To explore if, and in which ways, patients feel empowered } \\
\text { by participation in OSGs }{ }^{\text {b }}\end{array}$ \\
\hline $\begin{array}{l}\text { van Uden-Kraan et } \\
\text { al [32] }\end{array}$ & The Netherlands & $\begin{array}{l}\text { Retrospective online par- } \\
\text { ticipant survey }\end{array}$ & 528 respondents & $\begin{array}{l}\text { To explore if lurkers in Web-based patient support groups } \\
\text { profit to the same extent as posters do }\end{array}$ \\
\hline $\begin{array}{l}\text { van Uden-Kraan et } \\
\text { al [19] }\end{array}$ & The Netherlands & $\begin{array}{l}\text { Retrospective qualitative } \\
\text { content analysis }\end{array}$ & 1500 posts & $\begin{array}{l}\text { To explore the extent to which potential disadvantages ac- } \\
\text { tually occur when participating in OSGs }\end{array}$ \\
\hline $\begin{array}{l}\text { van Uden-Kraan et } \\
\text { al [18] }\end{array}$ & The Netherlands & $\begin{array}{l}\text { Retrospective online par- } \\
\text { ticipant survey }\end{array}$ & 528 respondents & $\begin{array}{l}\text { To explore the extent to which patients feel empowered by } \\
\text { their participation in OSGs and what processes occurring } \\
\text { in these groups are related to the empowering outcomes }\end{array}$ \\
\hline $\begin{array}{l}\text { van Uden-Kraan et } \\
\text { al [23] }\end{array}$ & The Netherlands & $\begin{array}{l}\text { Semistructured inter- } \\
\text { views }\end{array}$ & 23 Web-masters & $\begin{array}{l}\text { To determine the success factors of OSGs for patients and } \\
\text { the motives and goals of people who start such groups }\end{array}$ \\
\hline $\begin{array}{l}\text { van Uden-Kraan et } \\
\text { al [33] }\end{array}$ & The Netherlands & $\begin{array}{l}\text { Prospective participant } \\
\text { survey }\end{array}$ & 679 respondents & $\begin{array}{l}\text { To explore factors that facilitate or impede engagement in } \\
\text { face-to-face and Web-based peer support }\end{array}$ \\
\hline $\begin{array}{l}\text { van der Vaart et al } \\
\text { [34] }\end{array}$ & The Netherlands & $\begin{array}{l}\text { Prospective participant } \\
\text { survey }\end{array}$ & 227 respondents & $\begin{array}{l}\text { To examine current disease-related internet use and inten- } \\
\text { tions to use various Web-based support services on a hos- } \\
\text { pital-based interactive health communication app of patients } \\
\text { with rheumatic diseases }\end{array}$ \\
\hline Walker [35] & United States & $\begin{array}{l}\text { Retrospective qualitative } \\
\text { content analysis }\end{array}$ & 292 posts & $\begin{array}{l}\text { To explore how a relatively new medium of a disease- } \\
\text { specific Facebook group is used to address needs of people } \\
\text { affected by thoracic outlet syndrome }\end{array}$ \\
\hline Willis [21] & United States & $\begin{array}{l}\text { Retrospective qualitative } \\
\text { discourse analysis (eth- } \\
\text { nomethodology) }\end{array}$ & $\begin{array}{l}5 \text { members, } 8231 \\
\text { posts }\end{array}$ & $\begin{array}{l}\text { To understand how patients with arthritis use Web-based } \\
\text { health communities to exchange disease-related information } \\
\text { to better manage their chronic disease }\end{array}$ \\
\hline Willis [20] & United States & $\begin{array}{l}\text { Retrospective qualitative } \\
\text { discourse analysis (eth- } \\
\text { nomethodology) }\end{array}$ & 8231 posts & $\begin{array}{l}\text { To examine self-efficacy within the computer-mediated } \\
\text { communication of } 4 \text { Web-based health communities used } \\
\text { by people with arthritis }\end{array}$ \\
\hline $\begin{array}{l}\text { Willis and Royne } \\
\text { [22] }\end{array}$ & United States & $\begin{array}{l}\text { Retrospective quantita- } \\
\text { tive content analysis }\end{array}$ & 1960 posts & $\begin{array}{l}\text { To examine the computer-mediated communication within } \\
\text { Web-based health communities for evidence of chronic } \\
\text { disease self-management behaviors }\end{array}$ \\
\hline
\end{tabular}




\begin{tabular}{lllll}
\hline References & Country $^{\mathrm{a}}$ & Study design & $\begin{array}{l}\text { Sample size/sam- } \\
\text { ple volume }\end{array}$ & Study aim \\
\hline Xing et al [36] & United States & $\begin{array}{l}\text { Retrospective content } \\
\text { analysis and survival } \\
\text { analysis }\end{array}$ & $\begin{array}{l}100,000 \text { users, } \\
200,000 \text { user } \\
\text { posts }\end{array}$ & $\begin{array}{l}\text { To understand how requests for and provisions of informa- } \\
\text { tional support by members with different social roles influ- } \\
\text { ence members' continued participation in Web-based health } \\
\text { communities }\end{array}$ \\
\hline
\end{tabular}

${ }^{\mathrm{a}}$ Origin of online support groups when they are multinational.

${ }^{\mathrm{b}} \mathrm{OSG}$ : online support group.

\section{Quality Assessment of Quantitative Studies}

Of the 20 included studies, 10 included a quantitative component (Multimedia Appendix 3). Overall, 7 studies were rated as low risk of bias [22,27-33], and 3 studies were rated as moderate risk of bias $[18,29]$. Of the studies with a moderate risk of bias, 2 used multiple outcome measures to describe or quantify a single variable or concept, subsequently performing multiple analyses on a single research question [18,19].

\section{Design Features of Online Support Groups}

Characteristics of the design and features of the OSGs are described in Tables 1 and 2. Of the 20 studies, 13 (65\%) used platforms that were publicly accessible, 7 (36\%) [24,26,34] were private platforms designed specifically for the study, and 1 study (15\%) did not report the type of platform [33]. The most common type of platform was a purpose-built website $(13 / 20$, $65 \%)$. English language platforms were used by $52 \%(11 / 20)$ studies [20-22,24,26,28-31,35,36], whereas 42\% (8/20) studies used Dutch platforms [17-19,23,25,32-34] and 1 study used an Italian platform [27]. There were 6 studies [21,24,25,28,30,31] that reported the number of OSG members, which ranged from 12 to 374 people (Table 1 ). The number of posts examined for content was reported by 10 studies [20-22,24,28,30-32,35,36], ranging from 223 to 200,000 (Table 1). The average duration of membership for the platforms ranged from 4 weeks to 6 years.

Moderation of the OSG was used in 6 studies [23-25,30-32] (Table 2). Moderators were participants with musculoskeletal disorders (4 studies) [23,25,31,32], health professionals (1 study) [24], and organizers or administrators (1 study) [30]. The type of moderation consisted of supportive tasks, sharing experiences, facilitating information sharing, making announcements, administrative tasks (eg, removal of disadvantaged posts, monitoring members' activity, and maintaining the rules of the OSG), and leading group activities (eg, chat and discussion forums). 
Table 2. Description of online support groups included for review.

\begin{tabular}{|c|c|c|c|c|c|c|}
\hline References & Target population & Type of platform & $\begin{array}{l}\text { Duration of } \\
\text { OSG }^{\mathrm{a}}\end{array}$ & Language & Frequency of posts & $\begin{array}{l}\text { Presence/source of } \\
\text { moderation }\end{array}$ \\
\hline $\begin{array}{l}\text { Ammerlaan et } \\
\text { al [25] }\end{array}$ & $\begin{array}{l}\text { Young adults (age 16-25 } \\
\text { years) with arthritis }\end{array}$ & $\begin{array}{l}\text { Private website; } \\
\text { planned weekly chat } \\
\text { group ( } 90 \mathrm{~min})\end{array}$ & 6 weeks & Dutch & $\mathrm{NR}^{\mathrm{b}}$ & Yes/peer \\
\hline Bright et al [26] & $\begin{array}{l}\text { Adults with knee prob- } \\
\text { lems }\end{array}$ & $\begin{array}{l}\text { Private website } K N E E \text { - } \\
\text { guru }\end{array}$ & 1 month & English & NR & No \\
\hline $\begin{array}{l}\text { Camerini et al } \\
{[27]}\end{array}$ & Adults with FMS ${ }^{\mathrm{c}}$ & $\begin{array}{l}\text { Private website; also } \\
\text { included video and tex- } \\
\text { tual material on coping }\end{array}$ & $\begin{array}{l}\text { Mean } 167 \text { days } \\
(\mathrm{SD} 67.6)\end{array}$ & Italian & NR & No \\
\hline $\begin{array}{l}\text { Hadert and } \\
\text { Rodham [28] }\end{array}$ & Adults with arthritis & Public website & 3 months & English & NR & No \\
\hline $\begin{array}{l}\text { Shigaki et al } \\
\text { [29] }\end{array}$ & Adults with $\mathrm{RA}^{\mathrm{d}}$ & Private website & 10 weeks & English & NR & No \\
\hline Smarr et al [24] & Adults with RA & $\begin{array}{l}\text { Private website with } \\
\text { multiple shared re- } \\
\text { sources (eg, education } \\
\text { material and audio } \\
\text { files) }\end{array}$ & $\begin{array}{l}\text { Average of } 10 \\
\text { weeks }\end{array}$ & English & NR & $\begin{array}{l}\text { Yes/health profes- } \\
\text { sional }\end{array}$ \\
\hline $\begin{array}{l}\text { Smedley et al } \\
{[30]}\end{array}$ & Adults with CRPS & 4 private forums & 6 months & English & $\begin{array}{l}\text { 17=low frequency } \\
\text { posters }{ }^{\mathrm{f}} \text { (average } 9.5 \\
\text { posts); } 6=\text { high-fre- } \\
\text { quency posters }\end{array}$ & Yes/peer \\
\hline $\begin{array}{l}\text { Smedley et al } \\
{[31]}\end{array}$ & $\begin{array}{l}\text { Adults with arthritis, } \\
\text { CRPS, Crohn disease, } \\
\text { depression, Huntington } \\
\text { disease, and diabetes }\end{array}$ & $\begin{array}{l}6 \text { public discussion fo- } \\
\text { rums }\end{array}$ & NR & English & $\begin{array}{l}15 \text { posts per modera- } \\
\text { tor }\end{array}$ & Yes/peer \\
\hline $\begin{array}{l}\text { van Uden- } \\
\text { Kraan et al [17] }\end{array}$ & $\begin{array}{l}\text { Adults with arthritis, } \\
\text { FMS, or breast cancer }\end{array}$ & 9 public websites & NR & Dutch & $\begin{array}{l}\text { Posters }>1 / \text { day }=140 ; \\
1 / \text { day }=121 ; \\
>1 / \text { week }=96 ; \\
1 / \text { week }=31 ; \\
1 / \text { month }=6 ; \text { and } \\
<1 / \text { month }=6\end{array}$ & No \\
\hline $\begin{array}{l}\text { van Uden- } \\
\text { Kraan et al [32] }\end{array}$ & $\begin{array}{l}\text { Adults with arthritis, } \\
\text { FMS, or breast cancer }\end{array}$ & 8 public websites & $\begin{array}{l}1 \text { year (range } 0-6 \\
\text { years) }\end{array}$ & Dutch & Minimum=1/day & Yes/peer \\
\hline $\begin{array}{l}\text { van Uden- } \\
\text { Kraan et al [19] }\end{array}$ & $\begin{array}{l}\text { Adults with arthritis, } \\
\text { FMS, or breast cancer }\end{array}$ & 8 public websites & 3 months & Dutch & 1 or 2 messages & No \\
\hline $\begin{array}{l}\text { van Uden- } \\
\text { Kraan et al [18] }\end{array}$ & $\begin{array}{l}\text { Adults with arthritis, } \\
\text { FMS, or breast cancer }\end{array}$ & Public websites & Up to 2.5 years & Dutch & $\begin{array}{l}\text { Posters }>1 / \text { day }=146 ; \\
1 / \text { day }=139 ; \\
>1 / \text { week }=124 ; \\
1 / \text { week }=50 ; \\
1 / \text { month }=13 ; \text { and } \\
<1 / \text { month }=13\end{array}$ & No \\
\hline $\begin{array}{l}\text { van Uden- } \\
\text { Kraan et al [23] }\end{array}$ & $\begin{array}{l}\text { Adults with arthritis, } \\
\text { FMS, or breast cancer }\end{array}$ & $\begin{array}{l}10 \text { Public websites, } 13 \\
\text { private websites, } 18 \\
\text { stand-alone (not embed- } \\
\text { ded in organization } \\
\text { website/forum) OSGs, } \\
\text { and } 5 \text { patient advocacy } \\
\text { websites }\end{array}$ & NR & Dutch & $\begin{array}{l}\text { Ranged from a few } \\
\text { messages per week to } \\
\text { hundreds of messages } \\
\text { daily }\end{array}$ & Yes \\
\hline $\begin{array}{l}\text { van der Vaart et } \\
\text { al [34] }\end{array}$ & $\begin{array}{l}\text { Individuals with } \\
\text { rheumatic diagnosis }\end{array}$ & Private app & NR & Dutch & NR & No \\
\hline Walker [35] & $\begin{array}{l}\text { Adults with thoracic out- } \\
\text { let syndrome }\end{array}$ & $\begin{array}{l}\text { Public; hosted on Face- } \\
\text { book }\end{array}$ & 7 months & English & NR & NR \\
\hline Willis [21] & Adults with arthritis & 4 public websites & NR & English & Once every 4 days & No \\
\hline Willis [20] & Adults with arthritis & 4 public websites & NR & English & $\begin{array}{l}\text { Only high-frequency } \\
\text { posters participated }\end{array}$ & No \\
\hline
\end{tabular}




\begin{tabular}{|c|c|c|c|c|c|c|}
\hline References & Target population & Type of platform & $\begin{array}{l}\text { Duration of } \\
\mathrm{OSG}^{\mathrm{a}}\end{array}$ & Language & Frequency of posts & $\begin{array}{l}\text { Presence/source of } \\
\text { moderation }\end{array}$ \\
\hline $\begin{array}{l}\text { Willis and } \\
\text { Royne [22] }\end{array}$ & Adults with arthritis & 4 public websites & 4 weeks & English & NR & No \\
\hline Xing et al [36] & $\begin{array}{l}\text { Individuals with (or asso- } \\
\text { ciated with) FMS }\end{array}$ & Public website & Up to 6 years & English & $\begin{array}{l}\text { Core group members: } \\
\text { average of } 393 \text { posts; } \\
\text { peripheral members: } \\
9.58 \text { posts }\end{array}$ & Possible \\
\hline
\end{tabular}

a OSG: online support group.

${ }^{\mathrm{b}} \mathrm{NR}$ : not reported.

${ }^{\mathrm{c}} \mathrm{FMS}$ : fibromyalgia.

${ }^{\mathrm{d}} \mathrm{RA}$ : rheumatoid arthritis.

${ }^{\mathrm{e}} \mathrm{CRPS}$ : complex regional pain syndrome.

${ }^{f}$ Poster: people who write comments on online support group pages.

\section{Characteristics of Individuals Involved in Online Support Groups}

Participant characteristics were reported to varying degrees of detail across studies (Table 3). Participants' age was reported in 8 studies [20,25-27,29,30,33,34], which ranged from 18 to 83 years. Of the 1370 participants in the 8 studies reporting gender [20,25-27,29,30,33,34], 1092 (80\%) were female. Education history was reported in 6 studies [25-27,29,33,34]. Of the 1252 participants accounted for, 499 (39\%) had a maximum of low-tier education, but this category was not defined by the studies' authors. Occupational status was reported in 3 studies [26,33], accounting for 1068 participants, of which $643(60 \%)$ were unemployed. Relationship status was reported in 4 studies [26,29,33,34], with 836 of $1071(78 \%)$ participants being married or cohabiting. All studies stated their disorder of interest. The most commonly encountered musculoskeletal disorders were unspecified types of arthritis [17-23,25,28,32,33] and fibromyalgia [17-19,23,25,27,32,36]. Moreover, 5 studies examined individuals with rheumatoid arthritis [24,25,29,33,34], and 2 studies each investigated rheumatic disease [28,34], chronic regional pain syndrome [30,31], and spondyloarthropathy [25,28].

Not all participants in each of the OSGs had a musculoskeletal problem (Table 3). Of the 15 studies that identified the roles of OSG members, 2 studies identified that health professionals were included in the group [24,32], and 3 studies included family members or acquaintances of people with the disorder $[23,32,35]$. Within groups of patient members, 3 studies identified that members could either be participants $(n=292)$ or moderators or peer leaders $(n=66)[25,31,32]$, and 2 studies separated members into active posters (core members) $(\mathrm{n}=460)$ or lurkers (peripheral members) $(\mathrm{n}=9429)[19,36]$. Peripheral members were noted to post significantly less frequently (mean 9.9 posts, SD 21.6) than core members (mean 393.5 posts, SD 372.9) [36], and lurkers, as by definition, did not post at all [19]. 
Table 3. Characteristics of online support group users.

\begin{tabular}{|c|c|c|c|c|c|c|}
\hline References & $\begin{array}{l}\text { Age (years), mean } \\
\text { (range or SD) }\end{array}$ & $\begin{array}{l}\text { Gender (fe- } \\
\text { male/male) }\end{array}$ & Education levels & Occupation & Marital status & Motivation for joining \\
\hline $\begin{array}{l}\text { Ammerlaan et } \\
\text { al [25] }\end{array}$ & 22 (range: $17-25)$ & $9 / 1$ & $\begin{array}{l}\text { Vocational training: } 1 \text {; } \\
\text { advanced vocational } \\
\text { training: } 7 \text {; college/uni- } \\
\text { versity: } 2\end{array}$ & $\mathrm{~N} / \mathrm{A}^{\mathrm{a}}$ & N/A & N/A \\
\hline Bright et al [26] & 40.1 & $93 / 59$ & $\begin{array}{l}\text { Higher education qualifi- } \\
\text { cations: } 114\end{array}$ & $\begin{array}{l}\text { Employed: } 87 \text {; un- } \\
\text { employed: } 65\end{array}$ & Cohabiting: 104 & $\begin{array}{l}\text { Emotional support (clarity } \\
\text { regarding advice and treat- } \\
\text { ments), social support } \\
\text { (sharing experiences and } \\
\text { information), and condi- } \\
\text { tion support (achieving a } \\
\text { sense of authority) }\end{array}$ \\
\hline $\begin{array}{l}\text { Camerini et al } \\
{[27]}\end{array}$ & 49 (range: $25-74$ ) & $199 / 10$ & $\begin{array}{l}8 \text { years of schooling: } 36 \text {; } \\
\text { high school/university: } \\
\text { 163; not reported: } 10\end{array}$ & $\mathrm{~N} / \mathrm{A}$ & $\mathrm{N} / \mathrm{A}$ & N/A \\
\hline $\begin{array}{l}\text { Hadert and } \\
\text { Rodham [28] }\end{array}$ & N/A & N/A & N/A & N/A & N/A & $\begin{array}{l}\text { Needing to be believed, } \\
\text { information exchange, } \\
\text { sharing support, and shar- } \\
\text { ing emotions }\end{array}$ \\
\hline $\begin{array}{l}\text { Shigaki et al } \\
\text { [36] }\end{array}$ & $\begin{array}{l}49.4 \text { (range: } 30.1- \\
68.5)\end{array}$ & $28 / 2$ & $\begin{array}{l}\text { Mean years of education: } \\
15 \text { (range: } 12-20 \text { ) years }\end{array}$ & N/A & Married: 19 & N/A \\
\hline Smarr et al [24] & N/A & N/A & N/A & N/A & N/A & N/A \\
\hline $\begin{array}{l}\text { Smedley et al } \\
{[30]}\end{array}$ & $\begin{array}{l}36.6 \text { (range: } 20- \\
54)^{\mathrm{b}}\end{array}$ & $18 / 5$ & N/A & N/A & N/A & $\mathrm{N} / \mathrm{A}$ \\
\hline $\begin{array}{l}\text { Smedley et al } \\
{[31]}\end{array}$ & N/A & N/A & N/A & N/A & N/A & N/A \\
\hline $\begin{array}{l}\text { van Uden- } \\
\text { Kraan et al [17] }\end{array}$ & 43 (range: $21-75$ ) & $30 / 2$ & $\begin{array}{l}\text { Lower: } 5 \text {; medium: } 14 \text {; } \\
\text { high: } 13\end{array}$ & $\begin{array}{l}\text { Unemployed/un- } \\
\text { able to work: } 25 \text {; } \\
\text { employed: } 7\end{array}$ & $\begin{array}{l}\text { Married/cohabit- } \\
\text { ing: } 26 \text {; not mar- } \\
\text { ried: } 6\end{array}$ & N/A \\
\hline $\begin{array}{l}\text { van Uden- } \\
\text { Kraan et al [32] }\end{array}$ & $\begin{array}{l}\text { Posters }^{\mathrm{c}}: 43 \text { (SD } \\
\text { 10.4); lurkers }{ }^{\mathrm{d}}: 47 \\
(\mathrm{SD} 9.9)\end{array}$ & $\begin{array}{l}\text { Posters: } \\
\text { 392/27; } \\
\text { lurkers: } \\
102 / 7\end{array}$ & $\begin{array}{l}\text { Posters-lower: } 129 \text {; } \\
\text { medium: } 170 \text {; high: } 111 \text {. } \\
\text { Lurkers-lower: } 42 \text {; } \\
\text { medium: 43; high: } 24\end{array}$ & $\begin{array}{l}\text { Posters-working } \\
>20 \text { hours: } 128 \text {; } \\
\text { working } \leq 20 \\
\text { hours: } 54 \text {; unem- } \\
\text { ployed: } 234 \text {. Lurk- } \\
\text { ers-working > } 20 \\
\text { hours: } 39 \text {; working } \\
\leq 20 \text { hours: } 11 \text {; un- } \\
\text { employed:59 }\end{array}$ & $\begin{array}{l}\text { Posters-in a rela- } \\
\text { tionship: } 331 \text {; sin- } \\
\text { gle: } 88 \text {. Lurk- } \\
\text { ers-in a relation- } \\
\text { ship: } 85 \text {; single: } 25\end{array}$ & N/A \\
\hline $\begin{array}{l}\text { van Uden- } \\
\text { Kraan et al [19] }\end{array}$ & 38 (range: 21-65) & $\begin{array}{l}\text { 293/29; un- } \\
\text { known: } 25\end{array}$ & N/A & N/A & N/A & N/A \\
\hline $\begin{array}{l}\text { van Uden- } \\
\text { Kraan et al [18] }\end{array}$ & 44 (range: 17-75) & $494 / 34$ & $\begin{array}{l}\text { Lower: } 171 \text {; medium: } \\
\text { 213; high: } 135\end{array}$ & $\begin{array}{l}\text { Working }>20 \\
\text { hours: } 167 \text {; work- } \\
\text { ing } \leq 20 \text { hours: } 65 \text {; } \\
\text { unemployed: } 293\end{array}$ & $\begin{array}{l}\text { In a relationship: } \\
415 \text {; single: } 113\end{array}$ & N/A \\
\hline $\begin{array}{l}\text { van Uden- } \\
\text { Kraan et al [23] }\end{array}$ & 46 (range: $24-65$ ) & $20 / 3$ & N/A & N/A & N/A & $\begin{array}{l}\text { Provide information and } \\
\text { social support }\end{array}$ \\
\hline $\begin{array}{l}\text { van Uden- } \\
\text { Kraan et al [33] }\end{array}$ & 54 (range: 18-75) & $571 / 106$ & $\begin{array}{l}\text { Lower: 404; medium: } \\
\text { 176; high: } 94\end{array}$ & $\begin{array}{l}\text { Employed: } 212 ; \\
\text { unemployed: } 447\end{array}$ & $\begin{array}{l}\text { Married/cohabit- } \\
\text { ing: } 530 \text {; single: } \\
128\end{array}$ & $\begin{array}{l}\text { Improve mental health and } \\
\text { past behaviors with sup- } \\
\text { port groups }\end{array}$ \\
\hline $\begin{array}{l}\text { van der Vaart et } \\
\text { al [35] }\end{array}$ & $52(\mathrm{SD} 11)$ & $143 / 84$ & $\begin{array}{l}\text { Lower: } 61 \text {; average: } 116 \text {; } \\
\text { high: } 46 \text {; unknown: } 4\end{array}$ & $\begin{array}{l}\text { Employed: } 119 ; \\
\text { unemployed: } 106\end{array}$ & $\begin{array}{l}\text { Married/cohabit- } \\
\text { ing: } 183 \text {; single: } \\
\text { 42; unknown: } 2\end{array}$ & $\begin{array}{l}\text { Poor mental health and } \\
\text { improving health literacy }\end{array}$ \\
\hline Walker [35] & N/A & N/A & $\mathrm{N} / \mathrm{A}$ & N/A & N/A & N/A \\
\hline Willis [21] & Range: $21-83$ & $15 / 5$ & N/A & N/A & N/A & N/A \\
\hline Willis [20] & Range: $21-83$ & $15 / 5$ & N/A & N/A & N/A & N/A \\
\hline
\end{tabular}




\begin{tabular}{|c|c|c|c|c|c|c|}
\hline References & $\begin{array}{l}\text { Age (years), mean } \\
\text { (range or SD) }\end{array}$ & $\begin{array}{l}\text { Gender (fe- } \\
\text { male/male) }\end{array}$ & Education levels & Occupation & Marital status & Motivation for joining \\
\hline $\begin{array}{l}\text { Willis and } \\
\text { Royne [22] }\end{array}$ & N/A & N/A & N/A & N/A & N/A & N/A \\
\hline Xing et al [36] & N/A & N/A & N/A & N/A & N/A & N/A \\
\hline
\end{tabular}

${ }^{\mathrm{a}} \mathrm{N} / \mathrm{A}$ : not applicable.

${ }^{\mathrm{b}}$ Age was available for 9 participants, and the duration of symptoms was available for 14 participants.

${ }^{c}$ Poster: people who write comments on online support group pages.

${ }^{\mathrm{d}}$ Lurker: people who read material without contributing posts to the forum.

${ }^{\mathrm{e}}$ People with good health literacy were more likely to use peer support services to further improve knowledge.

\section{Effectiveness of Online Support Groups}

Overall, 10 studies reported on measures of effectiveness from OSGs [17-22,25,27,29,30]. Effectiveness was conceptualized as the development of patient empowerment [17-19], social support [25,29,30], self-management processes [20,22,27], and health literacy $[21,27]$. In evaluating effectiveness, none of the studies considered clinical domains (eg, pain or physical function; Multimedia Appendix 4).

Themes and processes of developing social activity, empowerment, self-management, and health literacy were explored by 4 studies using qualitative study designs [17,20,29], by 5 studies using quantitative designs [18,19,22,27,30], and by 1 study using mixed method [25]. Using semistructured interviews with 32 OSG users with arthritis, fibromyalgia, or breast cancer, van Uden-Kraan et al [17] concluded that patient empowerment was achieved by (1) being better informed, (2) feeling more confident, (3) increasing social well-being and enhanced self-esteem, and (4) acceptance and coping with chronic disease. Information and support were also found to be important themes for developing self-management and social support. Moreover, 2 studies reported that approximately one-third of all user posts contained these themes [21,30]. Sharing personal and disease experiences, particularly from disease veterans, was important in the development of a social activity, self-management plans, and improving health literacy $[20,25]$. This frequently included posts on drug management (29.3\%) and symptom management (22.7\%) [22]. Other common themes in these latter 3 effectiveness domains were seeking emotional support, positive feedback, and reinforcement from the community [20,21,25,30] (Multimedia Appendix 4).

When quantifying the effectiveness of OSG participation, participants with arthritis aged 25 years or younger reported high levels (mean 8.4, range: 6-10) of satisfaction with goal attainment, using a 10-point numerical rating scale [25]. However, a survey of 528 individuals with fibromyalgia, arthritis, and breast cancer indicated that they were neutral or in agreement (scores of 3-4 on a 5-point Likert scale) with their achievement of (1) being better informed, (2) enhancing social well-being, and (3) improving illness acceptance as a result of their participation in an OSG [18]. Further exploration of these findings revealed that people who were more engaged, evidenced by visiting the site more frequently or making more posts, experienced greater gains in health literacy, self-esteem, and self-management than those who made fewer posts or lurked [19,27] (Multimedia Appendix 4). Willis and Royne [22] reported that improvements in mobility, flexibility, pain, and energy were among the most frequently reported benefits of participation across 4 arthritis OSGs; however, they also reported significant differences between OSGs, suggesting that the perceived benefits may be specific to a group. Multimedia Appendix 4 summarizes all measures used to investigate the effectiveness of OSGs.

\section{Implementation Strategies to Deliver Online Support Groups}

Overall, 7 studies [22,36] reported on the strategies used to implement OSGs. Groups tended to be either self-initiated by an individual sufferer of the disorder or by official consumer associations [32]. The latter were embedded within pre-existing websites containing health information, being either open access or available to subscribed members only [23]. We found 2 studies that used relevant stakeholders such as program moderators and/or patients in the development and testing of their OSG [24,25] and for its delivery [25].

One study reported that a key component of OSGs was to continually promote the group and keep it alive, which took considerable time and energy [23]. Strategies to do this included moderation, augmented learning, or a small core group of individuals who posted more frequently than more peripheral users. Moderating a group took approximately 10 to 15 hours per week (unspecific group size), which was often perceived by individual moderators as onerous [23]. In addition to moderation, 2 OSGs augmented learning by scheduling weekly group chats or setting homework tasks that centered around predetermined themes [24,25].

Member engagement, or staying in the OSG, was significantly associated with starting or contributing to threads and requesting information. Xing et al [36] reported that OSG members who start or contribute to threads 1 SD more frequently than average (range: 222 posts to 373 posts depending on group roles) were $20 \%$ more likely to stay engaged with the community. Similarly, OSG members who requested information 1 SD more frequently than average (approximately 16 information requests) were $29.3 \%$ more likely to remain in the group. Responding to questions or information requests also influenced member engagement. Posted questions generally received an answer within 24 hours, though a small number $(15 \%)$ of questions received no answer at all [37]. If an information request was responded to by someone other than a core group member (ie, a peripheral group member), the person who made the request was $11.4 \%$ more likely to leave the group [36]. Criticisms of 
OSG implementation were that the discussion posts contained casual chitchat [32], and some OSGs had become social clubs rather than a place to exchange information and share experience [23].

\section{Discussion}

\section{Principal Findings}

This systematic review has revealed that the design features and implementation strategies used by peer-to-peer OSGs for people with chronic musculoskeletal disorders vary widely. People across a broad demographic spectrum access OSGs; some people chose to post actively, whereas others take a passive approach. Self-efficacy, health literacy, and empowerment are the constructs most commonly explored in studies investigating the effectiveness of musculoskeletal-focused OSGs. Overall, the findings stimulate discussion around optimal design and implementation of OSGs as well as how their effectiveness might best be measured. These topics are recommended for future investigation, particularly for people with chronic musculoskeletal disorders.

\section{Comparison With Prior Work}

For individuals with chronic musculoskeletal disorders, accessibility to OSGs is not influenced by whether the group is publicly or privately hosted. On the basis of the available literature, this also seems to be the case for OSGs focused on individuals with opioid addiction [38], depression [37], and asthma [39]. The majority of OSGs included in this review were hosted on public platforms. Previously, issues regarding privacy and security offered to users of public platforms have been raised [40]. A study of Facebook users comparing the amount and type of information disclosed on public and private Facebook groups indicates that private groups may be preferred, especially by people with social anxiety, because of the perception of greater control over who people are communicating with as well as greater trust and security of their information [41]. Our findings suggest that privacy and security were not barriers to participation in OSGs for people with chronic musculoskeletal disorders, and they did not influence the themes of information being shared. This may, however, have been because of the majority of group members also having the focus disorder, rather than the wider social network found on Facebook; the prevalence of the disorders within the general community; or the similarity in characteristics between group members (ie, primarily females who were not currently working). It appears that for people with chronic musculoskeletal disorders, the internet provides acceptable accessible sources of peer support for individuals seeking it, regardless of the hosting platform.

When examining the characteristics of OSG members included in this review, the majority of musculoskeletal-focused OSG members were female, not currently in full-time employment, and cohabitating or married. There is a significant association between exhibiting a preference for Web-based communication and the duration of internet usage [42]. Web-based communication is one way for people who are not working full time to maintain social activity when their peers and partners are not present. An explanation for the higher proportion of females in OSGs could be that although men use the internet more, women have been faster to adopt and are more frequent users of social networking and Web-based chat programs [43]. Furthermore, arthritis and fibromyalgia, the musculoskeletal disorders most commonly encountered in this review, are more common in females [44,45]. Another factor explaining lower male representation may be the perceived stigmatization of men sharing disease experiences on the Web [46]. Increasing representation of men in OSGs may be one way to improve self-management of disorders such as low back pain, the leading cause of years lived with disability for males since 1990 [2].

In evaluating OSG effectiveness, this review found that studies focused on constructs such as empowerment, self-efficacy, confidence, social support, and knowledge. These outcomes are consistent with those reported across multiple OSGs [47]. However, the lack of randomized controlled trials means that no causal inference can be established regarding OSG participation and change in these constructs. Self-efficacy has been identified as a foundation of chronic disease self-management [48], and multiple cohorts and observational studies of nonmusculoskeletal disorders have reported significant positive effects on self-efficacy following participation in OSGs and peer mentoring [40,47,49,50]. Findings from this review suggest that the extent to which OSG participation results in individuals with chronic musculoskeletal disorders feeling informed, confident, accepting of their disease is limited $[18,19]$. Furthermore, individuals who lurked, or did not actively post to OSGs, scored lower in the constructs of social well-being and self-esteem than active posters [19]. Although the direction of this relationship cannot be determined (active participation in OSGs leading to higher levels of social well-being and self-esteem, or vice versa), these results suggest that the type of participation may have a mediating effect. This has important implications for the implementation of future OSGs, as it appears that efforts must be made to engage individuals actively to contribute to posts, share stories, or ask questions [40].

One potential implementation method to promote active posting among OSG participants is the presence of a professional moderator [51]. Less than one-third of the studies included in this review reported the presence of a moderator. Of these moderators, the majority were peers who had the focus disorder. Although there does not appear to be a difference in OSG effectiveness irrespective of whether the moderator is a peer or health professional [40,51], Young et al [38] observed high attrition rates among peer moderators themselves. The time burden and onerous tasks involved in peer moderation may be one reason for this. Furthermore, when OSG member queries are not responded by peer moderators or leaders, general group attrition increased [36]. A previous review of OSGs [47] identified that attrition rates are lower with professional moderators. As such, having health professionals as moderators may be one way to address attrition rates and engagement. Health professional involvement may also help alleviate some of the time burden associated with moderating and administration for the group.

Additional implementation strategies that were investigated by studies included in this review were pretesting of OSGs before 
wider release, embedding the OSG in familiar websites, and scheduling weekly events or homework. No study investigated or reported the effectiveness of these strategies. Having identified these implementation strategies, a recommended topic for future research would be comparing the success of such implementation strategies with respect to consumer engagement and efficacy.

\section{Limitations}

There are limitations that need to be considered when interpreting the findings of this review. The main limitation is that the health disorders of interest in several included studies were diverse, and in some cases, it was not possible to identify which data came from individuals with musculoskeletal disorders. There were 6 studies [17-19,23,31,32], primarily from a single research group, where data from individuals with musculoskeletal disorders could not always be distinguished from those with other chronic disorders. People with musculoskeletal disorders account for the majority of participants included in our data synthesis. Second, several included studies reported on the same group of OSGs. Although each of these studies explored different aspects of OSGs, the smaller overall sample limits generalizability. Third, many of the studies investigating the content of OSG posts only reported a summary of the most frequently occurring topics. As the general posting rate was low, this would overrepresent the attitudes and beliefs of individuals who were more actively engaged with the group. Fourth, all studies also focused on individuals who were already members of OSGs and often collected cross-sectional data, so it is impossible to determine change or development in outcomes over time. As such, it is difficult to attribute attitudes and beliefs regarding empowerment and self-efficacy to participation in OSGs or whether these were views formed before participating. Finally, as the focus of effectiveness evaluation was on attitudes and beliefs rather than health outcomes, the impact that OSGs have on clinical features and symptoms of musculoskeletal disorders could not be evaluated.

\section{Conclusions}

OSGs provide an opportunity for individuals with musculoskeletal disorders to support one another through the sharing of knowledge and experiences. Across the diverse range of designs, languages, included features, and delivery platforms, OSGs attract participation from people of all ages and education levels, although predominantly females. The level to which group members participate appears to be related to their perceived benefit in health literacy and empowerment. However, the lack of control groups in studies means that direct inferences cannot be assessed or established. Participation may be increased by strategies such as moderation or input by a health professional or expert peers, homework tasks, and scheduled weekly chats. Whether these strategies are effective requires further investigation.

\section{Acknowledgments}

Funding for this study was provided by a Program Grant (APP1091302) and Centre of Research Excellence Grant (APP1079078) from the National Health and Medical Research Council (NHMRC) of Australia. DH, KB, and PH (APP1102905) are supported by fellowships from the NHMRC.

\section{Conflicts of Interest}

DH provides consulting advice to Merck Serono, TLCBio, Pfizer, and Eli Lilly and company.

\section{Multimedia Appendix 1}

Search strategy built and conducted in PubMed.

[DOCX File, 12 KB-Multimedia Appendix 1]

\section{Multimedia Appendix 2}

Results of the quality assessment of qualitative study methods using the Critical Appraisal Skills Programme criteria.

[DOCX File, 15 KB-Multimedia Appendix 2]

\section{Multimedia Appendix 3}

Risk Of Bias In Non-Randomized Studies of Interventions for quantitative design studies.

[DOCX File, 22 KB-Multimedia Appendix 3]

\section{Multimedia Appendix 4}

Themes and magnitude of measure used to investigate the effectiveness of online support groups.

[DOCX File, 18 KB-Multimedia Appendix 4]

\section{References}

1. Cimmino MA, Ferrone C, Cutolo M. Epidemiology of chronic musculoskeletal pain. Best Pract Res Clin Rheumatol 2011 Apr;25(2):173-183. [doi: 10.1016/j.berh.2010.01.012] [Medline: 22094194] 
2. GBD 2017 Disease and Injury Incidence and Prevalence Collaborators. Global, regional, and national incidence, prevalence, and years lived with disability for 354 diseases and injuries for 195 countries and territories, 1990-2017: a systematic analysis for the Global Burden of Disease Study 2017. Lancet 2018 Nov 10;392(10159):1789-1858 [FREE Full text] [doi: 10.1016/S0140-6736(18)32279-7] [Medline: 30496104]

3. GBD 2016 Disease and Injury Incidence and Prevalence Collaborators. Global, regional, and national incidence, prevalence, and years lived with disability for 328 diseases and injuries for 195 countries, 1990-2016: a systematic analysis for the Global Burden of Disease Study 2016. Lancet 2017 Sep 16;390(10100):1211-1259 [FREE Full text] [doi: 10.1016/S0140-6736(17)32154-2] [Medline: 28919117]

4. Duffield SJ, Ellis BM, Goodson N, Walker-Bone K, Conaghan PG, Margham T, et al. The contribution of musculoskeletal disorders in multimorbidity: Implications for practice and policy. Best Pract Res Clin Rheumatol 2017 Apr;31(2):129-144 [FREE Full text] [doi: 10.1016/j.berh.2017.09.004] [Medline: 29224692]

5. Bodenheimer T, Lorig K, Holman H, Grumbach K. Patient self-management of chronic disease in primary care. J Am Med Assoc 2002 Nov 20;288(19):2469-2475. [doi: 10.1001/jama.288.19.2469] [Medline: 12435261]

6. National Clinical Guideline Centre (UK). NCBI - NIH. London: National Institute for Health and Care Excellence (UK); 2014 Feb. Osteoarthritis: Care and Management in Adults URL: https://www.ncbi.nlm.nih.gov/pubmed/25340227 [accessed 2020-02-19]

7. Smolen JS, Landewé R, Bijlsma J, Burmester G, Chatzidionysiou K, Dougados M, et al. EULAR recommendations for the management of rheumatoid arthritis with synthetic and biological disease-modifying antirheumatic drugs: 2016 update. Ann Rheum Dis 2017 Jun;76(6):960-977. [doi: 10.1136/annrheumdis-2016-210715] [Medline: 28264816]

8. National Guideline Centre (UK). NCBI - NIH. London: National Institute for Health and Care Excellence (UK); 2016 Nov. Low Back Pain and Sciatica in Over 16s: Assessment and Management URL: https://www.ncbi.nlm.nih.gov/pubmed/ 27929617 [accessed 2020-02-19]

9. Gallant MP. The influence of social support on chronic illness self-management: a review and directions for research. Health Educ Behav 2003 Apr;30(2):170-195. [doi: 10.1177/1090198102251030] [Medline: 12693522]

10. Lee SD, Arozullah AM, Cho YI. Health literacy, social support, and health: a research agenda. Soc Sci Med 2004 Apr;58(7):1309-1321. [doi: 10.1016/S0277-9536(03)00329-0] [Medline: 14759678]

11. Vandenbosch J, van den Broucke S, Vancorenland S, Avalosse H, Verniest R, Callens M. Health literacy and the use of healthcare services in Belgium. J Epidemiol Community Health 2016 Oct;70(10):1032-1038. [doi: 10.1136/jech-2015-206910] [Medline: 27116951]

12. Ethgen O, Vanparijs P, Delhalle $S$, Rosant S, Bruyère O, Reginster JY. Social support and health-related quality of life in hip and knee osteoarthritis. Qual Life Res 2004 Mar;13(2):321-330. [doi: 10.1023/B:QURE.0000018492.40262.d1] [Medline: 15085904]

13. Evers AW, Kraaimaat FW, Geenen R, Jacobs JW, Bijlsma JW. Pain coping and social support as predictors of long-term functional disability and pain in early rheumatoid arthritis. Behav Res Ther 2003 Nov;41(11):1295-1310. [doi: 10.1016/s0005-7967(03)00036-6] [Medline: 14527529]

14. Barak A, Boniel-Nissim M, Suler J. Fostering empowerment in online support groups. Comput Hum Behav 2008;24(5):1867-1883. [doi: 10.1016/j.chb.2008.02.004]

15. Critical Appraisal Skills Programme. CASP Checklists URL: https://casp-uk.net/casp-tools-checklists/ [accessed 2019-03-01]

16. Sterne JA, Hernán MA, Reeves BC, Savović J, Berkman ND, Viswanathan M, et al. ROBINS-I: a tool for assessing risk of bias in non-randomised studies of interventions. Br Med J 2016 Oct 12;355:i4919 [FREE Full text] [doi: 10.1136/bmj.i4919] [Medline: 27733354]

17. van Uden-Kraan CF, Drossaert CH, Taal E, Shaw BR, Seydel ER, van de Laar MA. Empowering processes and outcomes of participation in online support groups for patients with breast cancer, arthritis, or fibromyalgia. Qual Health Res 2008 Mar;18(3):405-417. [doi: 10.1177/1049732307313429] [Medline: 18235163]

18. van Uden-Kraan C, Drossaert C, Taal E, Seydel E, van de Laar M. Participation in online patient support groups endorses patients' empowerment. Patient Educ Couns 2009 Jan;74(1):61-69. [doi: 10.1016/j.pec.2008.07.044] [Medline: 18778909]

19. van Uden-Kraan CF, Drossaert CH, Taal E, Seydel ER, van de Laar MA. Self-reported differences in empowerment between lurkers and posters in online patient support groups. J Med Internet Res 2008 Jun 30;10(2):e18 [FREE Full text] [doi: 10.2196/jmir.992] [Medline: 18653442]

20. Willis E. Patients' self-efficacy within online health communities: facilitating chronic disease self-management behaviors through peer education. Health Commun 2016;31(3):299-307. [doi: 10.1080/10410236.2014.950019] [Medline: 26325224]

21. Willis E. The making of expert patients: the role of online health communities in arthritis self-management. J Health Psychol 2014 Dec;19(12):1613-1625. [doi: 10.1177/1359105313496446] [Medline: 23988679]

22. Willis E, Royne MB. Online health communities and chronic disease self-management. Health Commun 2017 Mar;32(3):269-278. [doi: 10.1080/10410236.2016.1138278] [Medline: 27218836]

23. van Uden-Kraan CF, Drossaert CH, Taal E, Seydel ER, van de Laar MA. Patient-initiated online support groups: motives for initiation, extent of success and success factors. J Telemed Telecare 2010;16(1):30-34. [doi: 10.1258/jtt.2009.001009] [Medline: 20086265] 
24. Smarr KL, Musser DR, Shigaki CL, Johnson R, Hanson KD, Siva C. Online self-management in rheumatoid arthritis: a patient-centered model application. Telemed J E Health 2011 Mar;17(2):104-110. [doi: 10.1089/tmj.2010.0116] [Medline: 21361817]

25. Ammerlaan J, van Os-Medendorp H, Scholtus L, de Vos A, Zwier M, Bijlsma H, et al. Feasibility of an online and a face-to-face version of a self-management program for young adults with a rheumatic disease: experiences of young adults and peer leaders. Pediatr Rheumatol Online J 2014 Mar 25;12:10 [FREE Full text] [doi: 10.1186/1546-0096-12-10] [Medline: 24666817]

26. Bright $\mathrm{P}$, Hambly $\mathrm{K}$, Tamakloe $\mathrm{S}$. What is the profile of individuals joining the KNEEguru online health community? A cross-sectional mixed-methods study. J Med Internet Res 2016 Apr 18;18(4):e84 [FREE Full text] [doi: 10.2196/jmir.5374] [Medline: 27089531]

27. Camerini L, Camerini A, Schulz PJ. Do participation and personalization matter? A model-driven evaluation of an Internet-based patient education intervention for fibromyalgia patients. Patient Educ Couns 2013 Aug;92(2):229-234. [doi: 10.1016/j.pec.2013.04.007] [Medline: 23664234]

28. Hadert A, Rodham K. The invisible reality of arthritis: a qualitative analysis of an online message board. Musculoskeletal Care 2008 Sep;6(3):181-196. [doi: $\underline{10.1002 / \mathrm{msc} .131]}$ [Medline: $\underline{18570188}$ ]

29. Shigaki CL, Smarr KL, Gong Y, Donovan-Hanson K, Siva C, Johnson RA, et al. Social interactions in an online self-management program for rheumatoid arthritis. Chronic Illn 2008 Dec;4(4):239-246. [doi: 10.1177/1742395308097862] [Medline: 19091932]

30. Smedley R, Coulson N, Gavin J, Rodham K, Watts L. Online social support for Complex Regional Pain Syndrome: A content analysis of support exchanges within a newly launched discussion forum. Comput Hum Behav 2015 Oct;51:53-63. [doi: $10.1016 /$ j.chb.2015.04.040]

31. Smedley RM, Coulson NS. A thematic analysis of messages posted by moderators within health-related asynchronous online support forums. Patient Educ Couns 2017 Sep;100(9):1688-1693. [doi: 10.1016/j.pec.2017.04.008] [Medline: $\underline{28454663}]$

32. van Uden-Kraan C, Drossaert C, Taal E, Lebrun C, Drossaers-Bakker K, Smit W, et al. Coping with somatic illnesses in online support groups: Do the feared disadvantages actually occur? Comput Hum Behav 2008;24(2):309-324. [doi: 10.1016/j.chb.2007.01.014]

33. van Uden-Kraan CF, Drossaert CH, Taal E, Smit WM, Bernelot Moens HJ, van de Laar MA. Determinants of engagement in face-to-face and online patient support groups. J Med Internet Res 2011 Dec 7;13(4):e106 [FREE Full text] [doi: 10.2196/jmir.1718] [Medline: 22155649]

34. van der Vaart R, Drossaert CH, Taal E, van de Laar MA. Patient preferences for a hospital-based rheumatology Interactive Health Communication Application and factors associated with these preferences. Rheumatology (Oxford) 2011 Sep;50(9):1618-1626. [doi: 10.1093/rheumatology/ker161] [Medline: 21551221]

35. Walker KK. Cognitive and affective uses of a thoracic outlet syndrome Facebook support group. Health Commun 2014 Sep;29(8):773-781. [doi: 10.1080/10410236.2013.800830] [Medline: 24171492]

36. Xing W, Goggins S, Introne J. Quantifying the Effect of Informational Support on Membership Retention in Online Communities through Large-Scale Data Analytics. Comput Hum Behav 2018 Sep;86:227-234. [doi: 10.1016/j.chb.2018.04.042]

37. Griffiths KM, Calear AL, Banfield M. Systematic review on Internet Support Groups (ISGs) and depression (1): Do ISGs reduce depressive symptoms? J Med Internet Res 2009 Sep 30;11(3):e40 [FREE Full text] [doi: 10.2196/jmir.1270] [Medline: 19793719]

38. Young SD, Koussa M, Lee S, Perez H, Gill N, Gelberg L, et al. Feasibility of a social media/online community support group intervention among chronic pain patients on opioid therapy. J Addict Dis 2018;37(1-2):96-101 [FREE Full text] [doi: 10.1080/10550887.2018.1557992] [Medline: 30614403]

39. Stewart M, Letourneau N, Masuda JR, Anderson S, McGhan S. Impacts of online peer support for children with asthma and allergies: It just helps you every time you can't breathe well". J Pediatr Nurs 2013;28(5):439-452. [doi:

10.1016/j.pedn.2013.01.003] [Medline: 23398896]

40. Cooper K, Schofield P, Klein S, Smith BH, Jehu LM. Exploring peer-mentoring for community dwelling older adults with chronic low back pain: a qualitative study. Physiotherapy 2017 Jun;103(2):138-145 [FREE Full text] [doi: 10.1016/j.physio.2016.05.005] [Medline: 27613081]

41. Green T, Wilhelmsen T, Wilmots E, Dodd B, Quinn S. Social anxiety, attributes of online communication and self-disclosure across private and public Facebook communication. Comput Hum Behav 2016 May;58:206-213. [doi: 10.1016/j.chb.2015.12.066]

42. Thayer SE, Ray S. Online communication preferences across age, gender, and duration of internet use. Cyberpsychol Behav 2006 Aug;9(4):432-440. [doi: 10.1089/cpb.2006.9.432] [Medline: 16901247]

43. Kimbrough AM, Guadagno RE, Muscanell NL, Dill J. Gender differences in mediated communication: Women connect more than do men. Comput Hum Behav 2013 May;29(3):896-900. [doi: 10.1016/j.chb.2012.12.005]

44. Wolfe F, Walitt B, Perrot S, Rasker JJ, Häuser W. Fibromyalgia diagnosis and biased assessment: Sex, prevalence and bias. PLoS One 2018;13(9):e0203755 [FREE Full text] [doi: 10.1371/journal.pone.0203755] [Medline: 30212526] 
45. van Vollenhoven RF. Sex differences in rheumatoid arthritis: more than meets the eye. BMC Med 2009 Mar 30;7:12 [FREE Full text] [doi: 10.1186/1741-7015-7-12] [Medline: 19331649$]$

46. Samulowitz A, Gremyr I, Eriksson E, Hensing G. 'Brave Men' and 'Emotional Women': A theory-guided literature review on gender bias in health care and gendered norms towards patients with chronic pain. Pain Res Manag 2018;2018:6358624 [FREE Full text] [doi: 10.1155/2018/6358624] [Medline: 29682130]

47. Merolli M, Gray K, Martin-Sanchez F. Health outcomes and related effects of using social media in chronic disease management: a literature review and analysis of affordances. J Biomed Inform 2013 Dec;46(6):957-969 [FREE Full text] [doi: 10.1016/j.jbi.2013.04.010] [Medline: 23702104]

48. Jackson M, Jones D, Dyson J, Macleod U. Facilitated group work for people with long-term conditions: a systematic review of benefits from studies of group-work interventions. Br J Gen Pract 2019 May;69(682):e363-e372. [doi: 10.3399/bjgp19X702233] [Medline: $\underline{\text { 30962225] }}$

49. Olsson CA, Boyce MF, Toumbourou JW, Sawyer SM. The role of peer support in facilitating psychosocial adjustment to chronic illness in adolescence. Clin Child Psychol Psych 2016 Jul;10(1):78-87. [doi: 10.1177/1359104505048793]

50. Lewis P, Klineberg E, Towns S, Moore K, Steinbeck K. The effects of introducing peer support to young people with a chronic illness. J Child Fam Stud 2016;25(8):2541-2553. [doi: 10.1007/s10826-016-0427-4]

51. Klemm P. Effects of online support group format (moderated vs peer-led) on depressive symptoms and extent of participation in women with breast cancer. Comput Inform Nurs 2012 Jan;30(1):9-18. [doi: 10.1097/NCN.0b013e3182343efa] [Medline: 22240564]

\section{Abbreviations \\ CASP: Critical Appraisal Skills Programme \\ NHMRC: National Health and Medical Research Council \\ OSG: online support group \\ ROBINS-I: Risk Of Bias In Non-Randomized Studies of Interventions}

Edited by G Eysenbach; submitted 09.08.19; peer-reviewed by C Barton, E Willis, N Coulson, S Atanasova; comments to author
O2.10.19; revised version received 27.11.19; accepted 02.02.20; published 24.04.20
Please cite as:
Maclachlan LR, Mills K, Lawford BJ, Egerton T, Setchell J, Hall LM, Plinsinga ML, Besomi M, Teo PL, Eyles JP, Mellor R, Melo L,
Robbins S, Hodges PW, Hunter DJ, Vicenzino B, Bennell KL
Design, Delivery, Maintenance, and Outcomes of Peer-to-Peer Online Support Groups for People With Chronic Musculoskeletal
Disorders: Systematic Review
J Med Internet Res 2020;22(4):e15822
URL: http://www.jmir.org/2020/4/e15822/
doi: $10.2196 / 15822$
PMID: $\underline{32329746}$

CLiam R Maclachlan, Kathryn Mills, Belinda J Lawford, Thorlene Egerton, Jenny Setchell, Leanne M Hall, Melanie L Plinsinga, Manuela Besomi, Pek Ling Teo, Jillian P Eyles, Rebecca Mellor, Luciano Melo, Sarah Robbins, Paul W Hodges, David J Hunter, Bill Vicenzino, Kim L Bennell. Originally published in the Journal of Medical Internet Research (http://www.jmir.org), 24.04.2020. This is an open-access article distributed under the terms of the Creative Commons Attribution License (https://creativecommons.org/licenses/by/4.0/), which permits unrestricted use, distribution, and reproduction in any medium, provided the original work, first published in the Journal of Medical Internet Research, is properly cited. The complete bibliographic information, a link to the original publication on http://www.jmir.org/, as well as this copyright and license information must be included. 